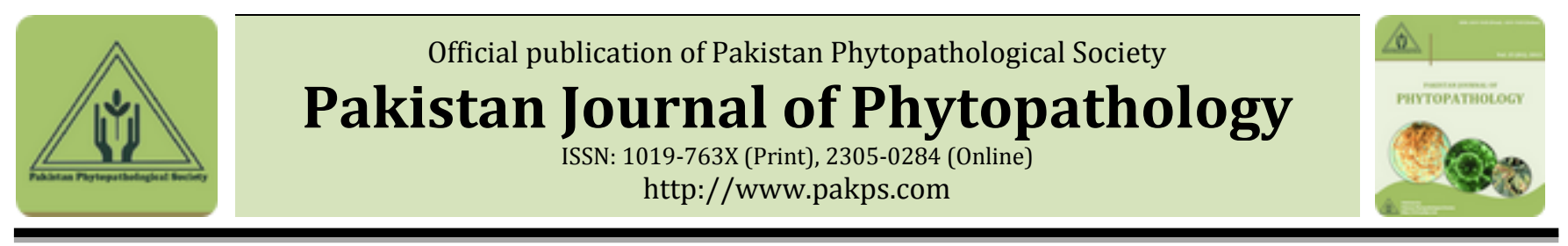

\title{
GENETIC DIVERSITY IN GOSSYPIUM HIRSUTUM (L.) FOR COTTON LEAF CURL DISEASE IN ASSOCIATION WITH AGRONOMIC AND FIBER TRAITS
}

\author{
aHasnain Raza, bIqrar A. Rana, aAmir Shakeel, cLori Hinze, cJames Frelichowski, adeMuhammad T. Azhar* \\ aDepartment of Plant Breeding \& Genetics, University of Agriculture, Faisalabad, Pakistan \\ ${ }^{\mathrm{d}}$ Climate Change Chair, US-Pakistan Centre for Advanced Studies in Agriculture and Food Security, Faisalabad, Pakistan \\ eSchool of Biological Sciences M084, The University of Western Australia, Australia \\ ${ }^{b}$ Centre of Agricultural Biochemistry and Biotechnology, University of Agriculture, Faisalabad, Pakistan \\ cUSDA-ARS, Crop Germplasm Research Unit, 2881 F\&B Road, College Station, TX 77845, USA
}

\begin{abstract}
A B S T R A C T
Knowledge of genetic diversity in terms of resistance or susceptibility to cotton leaf curl disease (CLCuD) and the agronomic value of economically important traits are essential. This is also required before starting a breeding program to develop disease resistant varieties. Germplasm comprising of 17 conventional cotton (Gossypium hirsutum L.) genotypes were screened under field conditions for the evaluation of resistance against CLCuD in addition yield and fiber quality traits were also measured. Disease scores revealed that none of the varieties were resistant to CLCuD. CIM-615, MARVI, and CIM-616 were tolerant to moderately tolerant while the S-12 genotype was highly susceptible to the disease. These three most tolerant genotypes, CIM-615, CIM-608 and CIM-616 had the highest metroglyph scores resulting from taller, higher yielding plants with stronger and more uniform fibers. Using the metroglyph analysis, these 17 genotypes were separated into seven groups. The separation of these genotypes into groups indicated the presence of genetic diversity, and superior parents from different groups that could be utilized for pyramiding genes governing yield and fiber related traits in addition to the disease tolerance into a single cotton genotype.
\end{abstract}

Keywords: Cotton Germplasm, Fiber traits, Metroglyph analysis, Tolerance, Susceptible

\section{INTRODUCTION}

Cotton (Gossypium hirsutum L.) is an important crop throughout the world because it provides employment to millions of people in various activities, i.e. industrial operation, research, seed production, and marketing. In Pakistan, agriculture has a substantial role in the economy and contributes about $21.4 \%$ in total gross domestic product (Anonymous, 2014-15). Stress due to environmental factors affects the expression of genotypic potential. Two types of environmental stresses can affect cotton production. These include biotic (pests, diseases, and weeds) and abiotic (high temperature, drought, and salinity) stresses. During the past two decades, cotton yields have been significantly reduced in Pakistan. Yields decreased by an estimated

* Corresponding Author:

Email: tehseenazhar@gmail.com

(C) 2017 Pak. J. Phytopathol. All rights reserved.
12 million bales from 2005 to 2008 primarily due to cotton leaf curl disease (CLCuD) (Briddon and Markham, 2000). CLCuD was reported for the first time in 1967 near the Multan district in Pakistan (Hussain and Ali, 1975). During an epidemic of CLCuD in the 1990s, it became a viable threat to cotton production. During this time, low production may have also been influenced by shortage of water, poor management of pests (including mealy bugs (Phenacoccus solenopsis Tinsley), and sowing of uncertified cottonseed.

The presence of CLCuD can significantly decrease boll weight by $33.8 \%$, number of bolls per plant by $73.5 \%$, gin outturn (GOT) up to $3.93 \%$, seed index $17 \%$ and yield of seed cotton per plant up to $64.5 \%$ (Ahmed, 1999). Significant improvements in cotton production for Pakistan have been made using cotton breeding in the last four decades. The foremost 
successes of cotton breeding include enhancement in yield, quality, earliness, adaptability to environmental conditions, and resistance to insects and diseases. Despite of these advances, Pakistan lags behind other cotton growing countries of the world in production of cotton per unit area. To change this trend, available genetic resources and information need to be appropriately exploited. Development of new varieties with high yield and enhanced quality parameters with tolerance to CLCuD is the goal of cotton breeders in Pakistan. At present, different levels of tolerance exist in cotton germplasm, but no single genotype is completely resistant to CLCuD. The sources of tolerance to CLCuD are limited, and understanding the genetic diversity within these sources is the pre-requisite to start a breeding program to improve this desirable trait (Mohammadi and Prasanna, 2003; Chen and Du, 2006). Since we have limited sources of tolerance, over time genetic diversity is going to narrow due to re-selection within and hybridization of similar parental lines (Brubaker et al., 1999; Tyagi et al., 2014).

For sustainable production, the CLCuD problem was addressed through conventional and nonconventional techniques in G. hirsutum (Farooq et al., 2011), and the tested germplasm had differential responses to CLCuD (Ahmad et al., 2010). Likewise, the herbarium of wild species of Gossypium were screened for resistance to CLCuD at the Central Cotton Research Institute (CCRI) in Multan, Pakistan under inoculum pressure of CLCuD. All of these species belong to various genomes were found to be asymptomatic for CLCuD (Azhar et al., 2010,). In a separate study, Azhar et al. (2013) confirmed the D genome species, $G$. gossypioides, as a source of resistance against CLCuD. This species could be used to map resistance by developing segregating populations and for the development of synthetic allotetraploids of cotton. However, since many of these species are diploids rather than tetraploids, they are difficult to use in breeding programs to improve the commercially important tetraploid species. In the current study, conventional (nontransgenic) tetraploid cotton ( $G$. hirsutum) genotypes were screened for their response to CLCuD and measured for genetic variation of several quantitative traits.

\section{MATERIALS AND METHODS}

Cottonseeds of 17 genotypes were collected from various cotton research institutes/stations in Punjab (Table 1). The seed of these genotypes were grown during the 2014-15 season at the experimental area of the Department of Plant Breeding \& Genetics, University of Agriculture Faisalabad, Pakistan. Each genotype was grown in a randomized complete block design with three replications. Each genotype was planted in the field with a row-to-row distance of 75 $\mathrm{cm}$ and a plant-to-plant distance of $30 \mathrm{~cm}$. All the recommended agronomic practices for the growing region were followed from sowing till harvesting/picking. To increase the population of whitefly, which serves as vectors for CLCuD, no insecticidal spray was applied during the growing season.

Data on response to CLCuD was recorded every two weeks using the disease scale proposed by Akhtar et al. (2010) (Table 2). At harvest, eight plants were selected randomly from each genotype from each block, and data was recorded on plant height $(\mathrm{cm})$, number of bolls per plant, boll weight (g), ginning outturn (\%), and seed cotton yield per plant (g). After ginning of seed cotton, the lint was used to measure fiber quality characteristics including fiber length $(\mathrm{mm})$, fiber strength (g/tex), fiber fineness (micronaire), fiber uniformity (\%), short fiber index (\%), and fiber elongation (\%). These fiber traits were measured from a sample of 100 grams of lint using a Spin lab HVI-900 available in the Department of Fiber Technology, University of Agriculture Faisalabad (Pakistan). Mean values of these quantitative traits and the disease score of CLCuD were statistically analyzed using analysis of variance (Steel et al., 1997) in Statix-8.1. Further, Pearson's correlation coefficient was calculated to assess associations between CLCuD, yield and fiber related traits following Steel and Torrie (1997). The same data were analyzed with the Metroglyph technique proposed by Anderson (1957) to determine genetic diversity and clustering of similar genotypes. Mean values of each trait were equally divided in three groups and index scores ranging from 1 to 3 were assigned to demonstrate the value of each trait. Traits with a higher index score of 3 reflect a favorable trait value. The accumulated scores across all traits depict the individual worth of a genotype. 
Pak. J. Phytopathol., Vol. 29 (01) 2017. 47-56

Table 1. List of varieties of G. hirsutum used in current study

\begin{tabular}{cccc}
\hline Code No. & Genotype & Code No. & Genotype \\
\hline V1 & MARVI & V10 & CIM-608 \\
\hline V2 & NIAB-465 & V11 & CIM-615 \\
\hline V3 & NIAB-777 & V12 & CIM-616 \\
\hline V4 & MAL-MAL & V13 & MNH-129 \\
\hline V5 & CIM-496 & V14 & MNH-534 \\
\hline V6 & CIM-534 & V15 & CIM-573 \\
\hline V7 & CIM-554 & V16 & CRIS-342 \\
\hline V8 & CIM-600 & V17 & S-12 \\
\hline V9 & CIM-607 & & \\
\hline
\end{tabular}

Table 2. Disease scale for cotton leaf curl disease (CLCuD)

\begin{tabular}{lcl}
\hline \multicolumn{1}{c}{ Symptoms } & $\begin{array}{c}\text { Disease } \\
\text { Scale }\end{array}$ & Disease response \\
\hline Complete absence of symptoms & 0 & Immune \\
\hline $\begin{array}{l}\text { Thickening of few small scattered veins or only presence of leaf enations on one or } \\
\text { few leaves of a plant. }\end{array}$ & 1 & Highly Resistant \\
\hline $\begin{array}{l}\text { Thickening of small group of veins, no leaf curling, no reduction in leaf size nor boll } \\
\text { setting. }\end{array}$ & 2 & Resistant \\
\hline $\begin{array}{l}\text { Thickening of all veins, minor leaf curling, and deformity of internode with minor } \\
\text { reduction in leaf size but no reduction in boll setting. }\end{array}$ & 3 & Moderately \\
\hline $\begin{array}{l}\text { Severe vein thickening, moderate leaf curling followed by minor deformity of } \\
\text { internodes and minor reduction in leaf size and boll setting. }\end{array}$ & 4 & $\begin{array}{l}\text { Moderately } \\
\text { Susceptible }\end{array}$ \\
\hline $\begin{array}{l}\text { Severe vein thickening, moderate leaf curling and deformity of internodes with } \\
\text { moderate reduction in leaf size and boll setting followed by moderate stunting. }\end{array}$ & 5 & Susceptible \\
\hline $\begin{array}{l}\text { Severe vein thickening, leaf curling, reduction in leaf size, deformed internodes and } \\
\text { stunting of the plant with no or few bolls set. }\end{array}$ & 6 & $\begin{array}{l}\text { Highly } \\
\text { Susceptible }\end{array}$ \\
\hline
\end{tabular}

\section{RESULTS}

Analysis of variance indicated that significant differences existed among the genotypes for all traits (data not shown). Results of each parameter based on mean values are discussed in the following paragraphs.

CLCuD score: Based on our rating of phenotypic symptoms, the lowest CLCuD score was obtained for CIM-615 (3.13) while the highest CLCuD score was noted for S-12 (5.67) (Table 3). Thus, CIM-615 showed significant tolerance against the disease whereas S-12 was highly susceptible. Additional moderately resistant genotypes exhibiting fewer viral symptoms included: MARVI (3.33), CIM-616 (3.33), CIM-608 (3.47), CRIS-342 (3.5), MNH-129 (3.6), CIM573 (3.73), MNH-534 (3.8) and NIAB-465 (3.8). Both NIAB-777 (5.07) and MAL-MAL (5.07) showed severe symptoms of $\mathrm{CLCuD}$ with a susceptible disease response.

Plant height: Significant differences were observed in plant height, as measurements ranged from $93-73 \mathrm{~cm}$ (Table 3). The tallest plants were observed for CIM496 and the shortest plants were observed for CIM-
554. An increasing incidence of CLCuD was associated with the presence of reduced plant height (Table 6). For example, CIM-496 was less affected by CLCuD (4.47) and had a good plant height $(93 \mathrm{~cm})$. In comparison, S-12 and CIM-554 were severely affected by $\mathrm{CLCuD}$ (5.67 and 4.07, respectively) and their plants were very short plants $(74.33$ and $73 \mathrm{~cm}$, respectively).

Seed cotton yield/plant: The genotype CIM-496 exhibited highest seed cotton yield/plant i.e. (37.29 g) as compared to MNH-129 (10.17 g) (Table 3). The results revealed that CIM-496 produced bolls having more weight but production of seed cotton of $\mathrm{MNH}$ 129 per plant was significantly reduced due to a severe infection of CLCuD. Overall reduction in seed cotton yield was attributed to susceptibility to CLCuD i.e. CIM-607 (11.03 g), S-12 (11.13 g), CIM-600 (12.83 g) and CIM-573 (14.46 g).

Number of bolls/plant: The presence of CLCuD was one of the major reasons for observing fewer bolls per plant. The maximum number of bolls/plant was observed in CIM-616 (20 bolls) and the fewest were counted in CIM-600 (3.33 bolls) (Table 3). This 
decrease in number of bolls in CIM 600 was linked to severe incidence of CLCuD (4.4) (Table 6). In contrast, CIM-616 was able to produce more bolls due to competitive tolerance to CLCuD (3.33). Other genotypes with reduced numbers of bolls per plant included S-12 (6 bolls), MARVI (7 bolls), NIAB-777 (8 bolls), CIM-573 (9.33 bolls) and CIM-615 (9.67 bolls).

Boll weight: The highest boll weight was observed in CIM-496 (3.65 g), and the lowest was measured in S-12 (2.68 g) (Table 3). The presence of CLCuD can also cause immature and small bolls, which leads to a loss in weight (Table 6). A differential response of genotypes was observed. The CIM-600 genotype produced bolls with weight ( $3.58 \mathrm{~g}$ ) similar to that of CIM-496. The S-12 genotype was severely affected by CLCuD and it showed a corresponding decrease in boll weight (2.68 g). Other genotypes which showed reduction in boll weight were CIM-534 (2.8 g), CIM554 (2.87 g), MARVI (2.95 g) and MAL-MAL (3 g).

Ginning outturn: The comparison of means of GOT\% showed that the cotton genotypes varied significantly from each other, and GOT\% was directly influenced by a severe incidence of CLCuD (Table 6). The maximum GOT\% (39.22\%) was found for NIAB-777 followed by CIM-600 (39.12\%) and CIM-608 (38.63\%) (Table 3). Due to the low seed cotton yield in most of the genotypes, the GOT\% was also not up to the standards commonly seen in experiments not exposed to CLCuD. The lowest GOT\% (22.55\%) was found for CIM-534 followed by CRIS-342 (28.49\%), MAL-MAL (30.6\%), CIM-496 (31.55\%), and S-12 (31.67\%).

Fiber fineness: CIM-608 and MNH-129 produced coarse fiber $(5.13 \mu \mathrm{g} / \mathrm{inch})$ while the finest fiber was observed in CIM-534 (3.27 $\mu \mathrm{g} /$ inch) (Table 3). It was noted that CIM-534 was severely affected by CLCuD (4.8), but it produced good quality fiber as shown by a negative correlation between these traits (Table 6). There was a mild reduction in fiber fineness due to susceptibility to CLCuD. The lower values for fiber fineness were measured for CIM-534 (3.27 ug/inch) and CIM-607 (3.5 ug/inch).

Fiber strength: The highest value for fiber strength was observed for CIM-607 (25.10 g/tex), and the lowest value was observed for S-12 (20.51 g/tex) (Table 3). The CIM-607 genotype was able to produce fibers with maximum strength while showing a moderately susceptible to/susceptible CLCuD rating.
In contrast, the $\mathrm{S}-12$ genotype as noted previously was severely affected by CLCuD and showed a significant decrease in fiber strength. Overall, there was a $5 \mathrm{~g} /$ tex difference in fiber strength across varying levels of susceptibility to CLCuD.

Fiber length: Significant differences were noted in the genotypes for fiber length. The maximum fiber length $(25.77 \mathrm{~mm})$ was found for CIM-600 followed by MNH-534 (25.6mm), CIM-607 $(25.27 \mathrm{~mm})$ and CIM$573(25.1 \mathrm{~mm})$ (Table 3). Fiber length was also affected by presence of CLCuD. Short fiber length was noted for S-12 (19.91mm) and NIAB-777 (22.07mm) which had high CLCuD scores. The genotypes NIAB$465(22.50 \mathrm{~mm})$, CRIS-342 $(22.67 \mathrm{~mm})$, and CIM-608 $(22.73 \mathrm{~mm})$ had short fibers and moderate susceptibility to CLCuD.

Fiber uniformity: Fiber uniformity was significantly reduced due to presence of CLCuD on planted genotypes. The maximum fiber uniformity (51.57\%) was found for CIM-573 followed by CIM-616 (51.33\%), CIM-608 (49.83\%) and CIM-615 (49.60\%) (Table 3). The fiber was least uniform (41.66\%) for the susceptible S-12 genotype. Other genotypes with minimal uniformity included CIM-496 (44.10\%), CIM607 (44.83\%), MNH-534 (45.60\%) and CIM-600 (46.0\%).

Short fiber index: The best values for short fiber index were found in CIM-554 (8.67\%), but the index was more than twice as high for NIAB-777 $(21.80 \%)$ (Table 3). Overall, there was increase in short fiber index due to infection of CLCuD. The cotton genotypes with the lowest short fiber indices included CIM-573 (9\%), S-12 (10.27\%), MNH-534 (10.87\%), CIM-496 (11.63\%), and CIM-607 (11.97\%).

Fiber elongation: The highest value for fiber elongation was observed in CIM-534 (7.93\%), and the lowest value was observed in S-12 (5.37\%) (Table 3). The remaining genotypes with fiber elongation greater than $7 \%$ included CIM-608 (7.63\%), MAL-MAL (7.37\%), CIM-496 (7.3\%), CRIS-342 (7.2\%), and CIM607 (7.17\%).

Anderson's Metroglyph analysis: Anderson's metroglyph is a technique used for preliminary grouping of genotypes based on phenotypic characters (Bhadra and Akhtar, 1991). The metroglyph analysis revealed four genotypes (CIM496, CIM-615, CIM-608, and CIM-616) with a high cumulative score of 27 indicating these genotypes 
have the most favorable combination of traits (Table 4). Genotype S-12 had the lowest cumulative score (16) which reflects its poor performance as previously noted for individual traits.

The two most variable characters (i.e., short fiber index and no of bolls/plant) were selected and plotted on the $\mathrm{x}$-axis and $\mathrm{y}$-axis, respectively, using the mean values of each genotype (Figure 1). The Metroglyph scatter diagram exhibited seven clusters of the 17 genotypes based on relative positioning of genotypes on the graph. The genotypes CIM-496, CIM-554, CIM-615, and CIM-573 were included in cluster I, while CIM-600, CIM-607, and MNH-534, were in cluster II (Table 5). NIAB-465, Mal-Mal, CIM534, CIM-608, and CIM-616 were included in cluster III. Cluster IV included two genotypes, NIAB-777 and CRIS-342. Cluster V, VI, and VII each included one genotype, MNH-129, S-12, and MARVI, respectively.

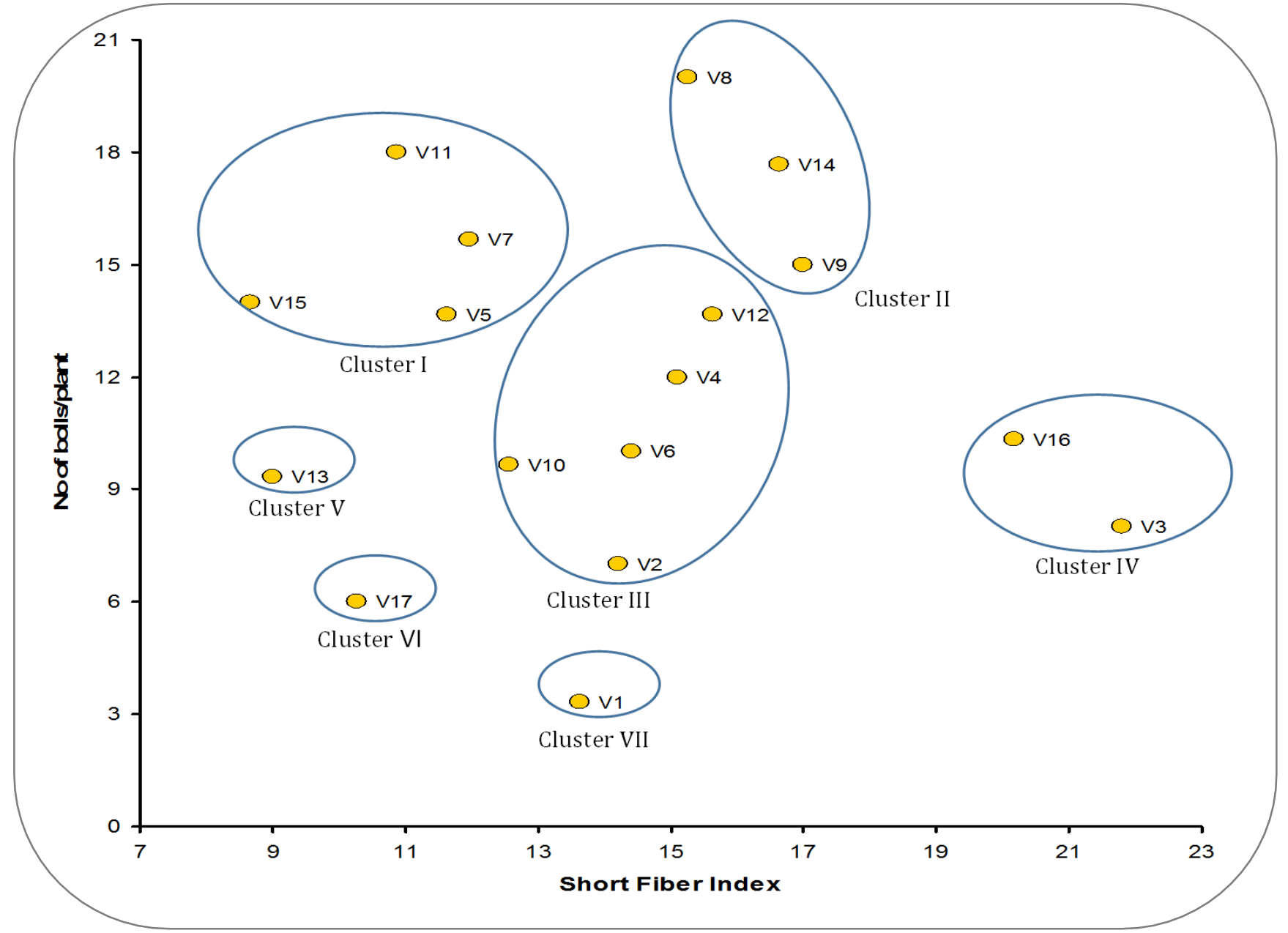

Figure 1. Metroglyph diagram illustrating distribution of various clusters formed from 17 genotypes using metroglyph analysis

Table 5. Cluster number, index scores and cotton genotypes included in each cluster based on the Metroglyph technique

\begin{tabular}{ccl}
\hline Cluster No. & Cluster Index & Genotypes \\
\hline I & 101 & CIM-496, CIM-554, CIM-615, CIM-573 \\
II & 76 & CIM-600, CIM-607, MNH-534 \\
III & 119 & NIAB-465, MAL-MAL, CIM-534, CIM-608, CIM-616 \\
IV & 47 & NIAB-777, CRIS-342 \\
V & 21 & MNH-129 \\
VI & 16 & S-12 \\
VII & 23 & MARVI \\
\hline
\end{tabular}




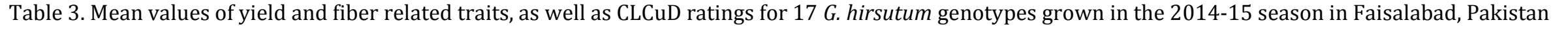

\begin{tabular}{|c|c|c|c|c|c|c|c|c|c|c|c|c|}
\hline Genotypes & $\begin{array}{c}\text { CLCuD } \\
\text { Score (0 } \\
-6 \\
\text { scale) }\end{array}$ & $\begin{array}{l}\text { Plant } \\
\text { height } \\
(\mathrm{cm})\end{array}$ & $\begin{array}{c}\text { Seed } \\
\text { cotton } \\
\text { yield } \\
\text { /plant } \\
\text { (g) }\end{array}$ & $\begin{array}{l}\text { No. of } \\
\text { bolls } \\
\text { /plant }\end{array}$ & $\begin{array}{c}\text { Boll } \\
\text { weight } \\
\text { (g) }\end{array}$ & $\begin{array}{l}\text { Ginning } \\
\text { outturn } \\
(\%)\end{array}$ & $\begin{array}{c}\text { Fiber } \\
\text { fineness } \\
\text { (micronaire) }\end{array}$ & $\begin{array}{c}\text { Fiber } \\
\text { strength } \\
\text { (g/tex) }\end{array}$ & $\begin{array}{c}\text { Fiber } \\
\text { length } \\
(\mathrm{mm})\end{array}$ & $\begin{array}{c}\text { Fiber } \\
\text { uniformity } \\
(\%)\end{array}$ & $\begin{array}{l}\text { Short } \\
\text { fiber } \\
\text { index } \\
(\%)\end{array}$ & $\begin{array}{c}\text { Fiber } \\
\text { elongation } \\
(\%)\end{array}$ \\
\hline CIM-600 & 4.40 & 73.67 & 12.83 & 3.33 & 3.58 & 39.12 & 4.33 & 24.43 & 25.77 & 46.00 & 13.63 & 6.93 \\
\hline MARVI & 3.33 & 82.33 & 17.67 & 7.00 & 2.95 & 33.59 & 4.33 & 22.97 & 24.43 & 47.90 & 14.20 & 6.53 \\
\hline NIAB-777 & 5.07 & 85.00 & 22.77 & 8.00 & 3.11 & 39.22 & 4.97 & 23.43 & 22.07 & 47.70 & 21.80 & 6.87 \\
\hline MAL-MAL & 5.07 & 77.67 & 16.12 & 12.00 & 3.00 & 30.60 & 4.33 & 23.13 & 23.43 & 48.00 & 15.10 & 7.37 \\
\hline CIM-496 & 4.47 & 93.00 & 37.29 & 13.67 & 3.65 & 31.55 & 4.63 & 23.03 & 24.53 & 44.10 & 11.63 & 7.3 \\
\hline CIM-534 & 4.80 & 80.00 & 24.01 & 10.00 & 2.80 & 22.55 & 3.27 & 22.83 & 23.73 & 47.40 & 14.40 & 7.93 \\
\hline CIM-607 & 4.67 & 75.33 & 11.03 & 15.67 & 3.08 & 34.78 & 3.50 & 25.10 & 25.27 & 44.83 & 11.97 & 7.17 \\
\hline CIM-616 & 3.33 & 90.67 & 32.01 & 20.00 & 3.46 & 36.44 & 4.90 & 23.93 & 23.40 & 51.33 & 15.27 & 6.07 \\
\hline CIM-608 & 3.47 & 82.00 & 27.34 & 15.00 & 3.10 & 38.63 & 5.13 & 24.00 & 22.73 & 49.83 & 17.00 & 7.63 \\
\hline CIM-615 & 3.13 & 89.00 & 32.54 & 9.67 & 3.10 & 35.91 & 4.60 & 24.07 & 24.47 & 49.60 & 12.57 & 6.53 \\
\hline MNH-534 & 3.80 & 81.67 & 24.03 & 18.00 & 3.14 & 35.76 & 4.67 & 24.53 & 25.60 & 45.60 & 10.87 & 5.73 \\
\hline MNH-129 & 3.60 & 79.33 & 10.17 & 13.67 & 3.38 & 33.01 & 5.13 & 23.53 & 23.43 & 47.33 & 15.63 & 6.27 \\
\hline CIM-573 & 3.73 & 74.00 & 14.46 & 9.33 & 3.07 & 38.22 & 4.87 & 24.27 & 25.10 & 51.57 & 9.00 & 6.23 \\
\hline CRIS-342 & 3.50 & 85.67 & 32.33 & 17.67 & 3.22 & 28.49 & 4.47 & 23.20 & 22.67 & 47.17 & 16.63 & 7.20 \\
\hline CIM-554 & 4.07 & 73.00 & 25.64 & 14.00 & 2.87 & 36.64 & 4.93 & 24.73 & 23.87 & 48.70 & 8.67 & 6.50 \\
\hline NIAB-465 & 3.80 & 74.00 & 16.67 & 10.33 & 3.43 & 38.07 & 4.33 & 21.50 & 22.50 & 46.37 & 20.17 & 6.83 \\
\hline S-12 & 5.67 & 74.33 & 11.13 & 6.00 & 2.68 & 31.67 & 4.11 & 20.51 & 19.91 & 41.66 & 10.27 & 5.37 \\
\hline CV\% & 18.072 & 7.890 & 38.324 & 38.294 & 8.571 & 12.867 & 11.565 & 4.933 & 6.228 & 5.350 & 25.759 & 10.065 \\
\hline
\end{tabular}




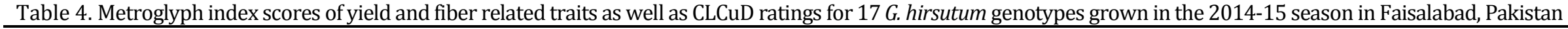

\begin{tabular}{|c|c|c|c|c|c|c|c|c|c|c|c|c|c|}
\hline Genotypes & $\begin{array}{c}\text { CLCuD } \\
\text { Score (0 - } \\
6 \text { scale) }\end{array}$ & $\begin{array}{l}\text { Plant } \\
\text { height } \\
(\mathrm{cm})\end{array}$ & $\begin{array}{c}\text { Seed } \\
\text { cotton } \\
\text { yield } \\
\text { /plant (g) }\end{array}$ & $\begin{array}{l}\text { No. of } \\
\text { bolls } \\
\text { /plant }\end{array}$ & $\begin{array}{c}\text { Boll } \\
\text { weight } \\
\text { (g) }\end{array}$ & $\begin{array}{l}\text { Ginning } \\
\text { outturn } \\
(\%)\end{array}$ & $\begin{array}{l}\text { Fiber fineness } \\
\text { (micronaire) }\end{array}$ & $\begin{array}{c}\text { Fiber } \\
\text { strength } \\
\text { (g/tex) }\end{array}$ & $\begin{array}{l}\text { Fiber } \\
\text { length } \\
(\mathrm{mm})\end{array}$ & $\begin{array}{c}\text { Fiber } \\
\text { uniformity } \\
(\%)\end{array}$ & $\begin{array}{c}\text { Short } \\
\text { fiber } \\
\text { index } \\
(\%)\end{array}$ & $\begin{array}{c}\text { Fiber } \\
\text { elongation } \\
(\%)\end{array}$ & $\begin{array}{l}\text { Total } \\
\text { Score }\end{array}$ \\
\hline CIM-600 & 2 & 1 & 1 & 1 & 3 & 3 & 3 & 3 & 3 & 1 & 2 & 2 & 25 \\
\hline MARVI & 3 & 2 & 2 & 1 & 1 & 2 & 3 & 1 & 2 & 2 & 2 & 2 & 23 \\
\hline NIAB-777 & 1 & 3 & 2 & 1 & 2 & 3 & 1 & 2 & 1 & 2 & 1 & 2 & 21 \\
\hline MAL-MAL & 1 & 2 & 1 & 2 & 1 & 1 & 3 & 1 & 2 & 2 & 2 & 3 & 21 \\
\hline CIM-496 & 2 & 3 & 3 & 2 & 3 & 1 & 2 & 1 & 3 & 1 & 3 & 3 & 27 \\
\hline CIM-534 & 1 & 2 & 2 & 2 & 1 & 1 & 3 & 1 & 2 & 2 & 2 & 3 & 22 \\
\hline CIM-607 & 1 & 1 & 1 & 3 & 2 & 2 & 3 & 3 & 3 & 1 & 3 & 2 & 25 \\
\hline CIM-616 & 3 & 3 & 3 & 3 & 3 & 2 & 1 & 2 & 1 & 3 & 2 & 1 & 27 \\
\hline CIM-608 & 3 & 2 & 3 & 3 & 2 & 3 & 1 & 2 & 1 & 3 & 1 & 3 & 27 \\
\hline CIM-615 & 3 & 3 & 3 & 1 & 2 & 2 & 2 & 2 & 2 & 3 & 2 & 2 & 27 \\
\hline MNH-534 & 2 & 2 & 2 & 3 & 2 & 2 & 2 & 3 & 3 & 1 & 3 & 1 & 26 \\
\hline MNH-129 & 3 & 2 & 1 & 2 & 3 & 1 & 1 & 2 & 2 & 2 & 1 & 1 & 21 \\
\hline CIM-573 & 2 & 1 & 1 & 1 & 1 & 3 & 2 & 3 & 3 & 3 & 3 & 1 & 24 \\
\hline CRIS-342 & 3 & 3 & 3 & 3 & 2 & 1 & 2 & 2 & 1 & 2 & 1 & 3 & 26 \\
\hline CIM-554 & 2 & 1 & 2 & 2 & 1 & 2 & 1 & 3 & 2 & 3 & 3 & 1 & 23 \\
\hline NIAB-465 & 2 & 1 & 2 & 2 & 3 & 3 & 3 & 1 & 1 & 1 & 1 & 2 & 22 \\
\hline S-12 & 1 & 1 & 1 & 1 & 1 & 1 & 3 & 1 & 1 & 1 & 3 & 1 & 16 \\
\hline
\end{tabular}

Table 6. Correlation coefficient analysis of yield and fiber related traits as well as CLCuD ratings for 17 G. hirsutum genotypes grown in the 2014-15 season in Faisalabad, Pakistan

\begin{tabular}{|c|c|c|c|c|c|c|c|c|c|c|c|c|}
\hline & $\begin{array}{l}\text { CLCuD } \\
\text { Score }\end{array}$ & $\begin{array}{l}\text { Plant } \\
\text { height }\end{array}$ & $\begin{array}{l}\text { Seed cotton } \\
\text { yield / plant }\end{array}$ & $\begin{array}{c}\text { No. of bolls } \\
\text { /plant }\end{array}$ & $\begin{array}{c}\text { Boll } \\
\text { weight }\end{array}$ & $\begin{array}{l}\text { Ginning } \\
\text { outturn }\end{array}$ & $\begin{array}{c}\text { Fiber } \\
\text { Fineness }\end{array}$ & $\begin{array}{c}\text { Fiber } \\
\text { strength }\end{array}$ & $\begin{array}{l}\text { Fiber } \\
\text { length }\end{array}$ & $\begin{array}{c}\text { Fiber } \\
\text { uniformity }\end{array}$ & $\begin{array}{c}\text { Short } \\
\text { fiber index }\end{array}$ & $\begin{array}{c}\text { Fiber } \\
\text { elongation }\end{array}$ \\
\hline CLCuD Score & 1 & & & & & & & & & & & \\
\hline Plant height & -0.338 & 1 & & & & & & & & & & \\
\hline Seed cotton yield /plant & -0.373 & 0.811 & 1 & & & & & & & & & \\
\hline No. of bolls /plant & -0.388 & 0.398 & 0.477 & 1 & & & & & & & & \\
\hline Boll weight & -0.342 & 0.369 & 0.240 & 0.196 & 1 & & & & & & & \\
\hline Ginning outturn & -0.282 & -0.153 & -0.128 & -0.104 & 0.327 & 1 & & & & & & \\
\hline Fiber fineness & -0.464 & 0.263 & 0.264 & 0.228 & 0.332 & 0.600 & 1 & & & & & \\
\hline Fiber strength & -0.379 & 0.055 & 0.144 & 0.366 & 0.189 & 0.357 & 0.227 & 1 & & & & \\
\hline Fiber length & -0.364 & 0.020 & 0.038 & 0.105 & 0.344 & 0.166 & -0.073 & 0.766 & 1 & & & \\
\hline Fiber uniformity & -0.626 & 0.181 & 0.274 & 0.229 & 0.038 & 0.290 & 0.466 & 0.469 & 0.235 & 1 & & \\
\hline Short fiber index & -0.047 & 0.228 & 0.060 & -0.019 & 0.282 & 0.100 & 0.122 & -0.270 & -0.391 & 0.123 & 1 & \\
\hline Fiber elongation & 0.085 & 0.127 & 0.247 & 0.031 & 0.112 & -0.334 & -0.327 & 0.139 & 0.142 & 0.118 & 0.385 & 1 \\
\hline
\end{tabular}




\section{DISCUSSION}

The breakdown of resistance due to evolution of the cotton leaf curl virus appears periodically and causes significant losses in crop production (Amrao et al., 2010). The breeding of resistant cultivars is an ongoing process of screening germplasm for new sources of resistance. When identified, this new germplasm may be used for the development of high yielding cultivars with enhanced levels of resistance to cotton leaf curl disease. In the current study, analysis of variance elucidated highly significant differences for yield and fiber related traits among the selected genotypes. The purpose of this study was to identify tolerant to moderate tolerant genotypes against CLCuD, because it is one of the most devastating cotton diseases on the Pak-Indo continent. CLCuD was found in isolated instances through the 1980s and did not cause a large economic impact. However, it appeared as an epidemic in the 1990s, spreading over 120,000 ha, and reducing production of seed cotton to $30 \%$ of average yields (Mansoor et al., 1993). During this epidemic, all cotton varieties showed a susceptible response, including the genotype S-12 evaluated in this study. The information reported by Briddon (2003) and Rahman et al. (2005) supported the findings presented here for $\mathrm{S}-12$ as it showed a susceptible response with a high disease score of 5.67. Subsequent to this epidemic, local cotton breeders have used highly tolerant (CP-15/2 and LRA-5166) exotic germplasm to develop resistant cultivars (Rashida et al., 2005. Rahman et al. (2005) The $\mathrm{F}_{1}$ developed by Rahman et al. (2005) by crossing LRA-5166 × S-12 and CP-15/2 × S-12 showed complete tolerance to CLCuD. The progeny segregated by a 13:3 ratio (tolerant : susceptible) indicating the value of tolerant lines in breeding programs. So, these two parents were used for the development of several genotypes of upland cotton varieties. One of these genotypes included CIM-615 which was evaluated in the current study had moderate resistance to $\mathrm{CLCuD}$, and it was released for general cultivation in Punjab and Singh provinces of Pakistan (Rahman et al., 2002; Ahmad et al., 2010). In addition to G. hirsutum cultivars, diploid wild relatives belonging to the D genome (e.g. G. gossypioides) could be used for development of synthetic tetraploids having resistance to CLCuD (Azhar et al., 2013). This disease affects metabolic pathways and suppresses the growth, development, and, ultimately, yield potential of the cotton plant. The negative association of CLCuD with quantitative traits measured in this study is supported by previous research (Russel, 1982; Harrison et al., 1997; Brown, 2001; Singh et al., 2013; Saeed et al., 2014) Bhadra and Akhtar (1991) concluded that Metroglyph analysis is an easy and robust technique for preliminary grouping of genotypes. In this study, a scatter diagram exhibited the formation of seven clusters of 17 genotypes of cotton. This analysis has scattered individual genotypes in various clusters based on phenotypic trait differences. The pattern of scattering of these genotypes provides clues for the presence of genetic diversity and the potential use of that diversity in breeding programs. Rashid et al., (2007) presents similar information, but deviation in placement of genotypes in various groups was due to variation in number of genotypes and the amount of diverse background in germplasm used in the study. Hybridization between genotypes from two distant clusters (i.e. Cluster-I and Cluster-III) is expected to generate germplasm with diverse genotypes (Singh and Narayanan, 1993). Several research workers have used this technique efficiently to identify distinct genotypes for improvement of certain traits in cotton (Shakeel et al., 2008; Shakeel et al., 2011), rice (Cheema et al., 2004), sugarcane (Mujahid et al., 2001) and brassica (Khan et al., 2005). The genotypes within a single group had less diversity from each other as compared to genotypes belonging to other groups based on yield and fiber related traits. Rabbani et al., (1998) and Grenier et al. ,2001) also reported the presence of genetic diversity in mustard and upland cotton, respectively, among various groups for various agronomical traits, and this genetic diversity has great value for selection of potential parental lines in a breeding program. Hybridization between genotypes within the same group may not provide good transgressive segregants due to lack of genetic diversity (May et al., 1995; Bowman et al., 1996; Pandey et al., 2016). We can conclude that information generated herein could be valuable in selecting the parental lines used in breeding programs to develop high yielding genotypes having tolerance to cotton leaf curl disease.

\section{REFERENCES}

Ahmad, S., N. U. Islam, A. Mahmood, F. Ashraf, K. Hayat and M. Hanif. 2010. Screening of cotton germplasm against cotton leaf curl virus. Pak. J. Bot. 42: 3327-3342.

Ahmed, Z. 1999. Prospects and bottlenecks of cotton crop in Pakistan. The Pak. Cotton Grower. 3: 6-7. 
Amrao, L., S. Akhter, M. N. Tahir, I. Amin, R. W. Briddon and S. Mansoor. 2010. Cotton leaf curl disease in Sindh province of Pakistan is associated with recombinant begomovirus components. Virus Res. 153:161-165.

Anderson, E. 1957. A semi graphical method for the analysis of complex problems. Proc. Nat. Acad. Sci. USA. 43: 923-927.

Anonymous. 2014-15. Pakistan Economic Survey. Govt. of Pakistan, Ministry of Finance, Economic advisor's Wing, Islamabad.

Akhtar, K. P., S. Haidar, M. K. R. Khan, M. Ahmad, N. Sarwar, M.A. Murtaza and M. Aslam. 2010. Evaluation of Gossypium species for resistance to cotton leaf curl Burewala virus. Ann. Appl. Biol. 157: $135-147$

Azhar, M. T., M. U. Rehman, S. Aftab, Y. Zafar and S. Mansoor. 2010. Utilization of geneticallyengineered sources in Gossypium hirsutum for the development of tolerance against cotton leaf curl disease and fiber characters. Int. J. Agric. Biol. 12: 744-748.

Azhar, M. T., Z. I. Anjum and S. Mansoor. 2013. Gossypium gossypioides: a source of resistance among cotton leaf curl disease among D genome diploid cotton species. J. Anim. and Pla. Sci. 23(5): 1436-1440.

Bhadra, S. K. and M. I. Akhtar. 1991. Genetic divergence for yield and its morphological component of mungbean (Vigna radiata L.). SABRAO. J. 23:127-136.

Bowman, D. T., O. L. May and D. S. Calhoun. 1996. Genetic base of upland cotton cultivars released between 1970 and 1990. Crop Sci. 36:577-581.

Brown, J.K. 2001. Viral and phytoplasma disease: Cotton leaf curl disease. p. 52-54. In: Compendium of cotton disease. (Eds.): T.L Kirkpatrick and C.K. Rothrock. 2nd ed. American psychopathological Society, St.Paul, MN.

Briddon, R. W. and P. G. Markham. 2000. Cotton leaf curl virus disease. Virus Res. 71: 151-159.

Briddon, R. W. 2003. Cotton leaf curl disease, a multicomponent begomovirus complex. Molecular Plant Pathol. 4 :427-434.

Brubaker, C. L., F. M. Bourland and J. F. Wendel. 1999. The origin and domestication of cotton. p. 3-31, In C. W. Smith and J. T. Cothren, eds. Cotton: origin, history, technology, and production. John Wiley \& Sons, Inc., New York.
Cheema, A. A., M. Rashid, M. Ashraf and Q. Zia-Ul. 2004. Genetic divergence rice collections. Pak. J. Bot. 36:557-566.

Chen, G. and X. M. Du. 2006. Genetic diversity of source germplasm of Upland cotton in China as determined by SSR marker analysis. Acta Genetica Sinica 33: 733-745.

Farooq, A., J. Farooq, A. Mahmood, A. Shakeel, A. Rehman, A. Batool and S. Mehboob. 2011. An overview of cotton leaf curl virus disease (CLCuD) a serious threat to cotton productivity. Aust. J. Crop Sci. 5: 1823-1831.

Grenier, C., M. Deu, S. Kresovich, P. J. Bramel Cox and P. Hamon. 2001. Assessment of genetic diversity in three subsets constituated from the ICRISAT sorgham collection using random vs. non-random sampling procedures by using molecular markers. Theor. App. Genet. 101: 197-202.

Harrison, B.D., Y.L. Liv, S. Khalid, S, Hameed, G.W. Otim Nape and D.J. Robinson. 1997. Detection and relationship of cotton leaf curl virus and allied white fly transmitted gemini viruses accruing in Pakistan. Ann. Appl. Biol. 130: 61-75.

Hussain, T. and M. Ali. 1975. A review of cotton diseases of Pakistan. Pak. Cotton. 19:71-86.

Khan, F. A., M. Younas, and G. Mustafa. 2005. Metroglyph analysis for the yield and quality related characters of Brassica juncea L. Int. J. Agric. Biol. 2:260-262.

Mansoor, S., I.D. Bedford, M.S. Pinner, J. Stanley and P.G. Markham. 1993. A whitefly- transmitted geminivirus associated with cotton leaf curl disease in Pakistan. Pak. J. Bot. 25: 105-107.

May, O. L., D. T. Bowman and D. S. Calhoun. 1995. Genetic diversity of U.S. Upland cotton cultivars released between 1980 and 1990. Crop Sci. 35:1570-1574.

Mohammadi, S. A. and B. M. Prasanna. 2003. Analysis of genetic diversity in crop plants - salient statistical tools and considerations. Crop Sci. 43: 1235-1248.

Mujahid, M., F. A. Khan and H. A. Sadaqat. 2001. Metroglyph and D2 analysis for estimation of potential for improvement in (Saccharum officinarum L.) accessions. Int. J. Agri. Biol. 3:47-50.

Pandey, V. R., P. Pandey, R. Kant and P. K. Singh. 2016. Assessment of genetic diversity using morphological traits in pigeon pea [Cajanus cajan (L.) Millsp.]. Elec. J. Plant Breed. 7: 496-504.

Rabbani, M. A., A. Iwabuchi, Y. Murakami, T. Suzuki and K. Takayanagi. 1998. Phenotypic variation and the 
Pak. J. Phytopathol., Vol. 29 (01) 2017. 47-56

relationships among mustard (Brassica juncea L.) germplasm from Pakistan. Euphytica. 101:357-366.

Russel, T. E. 1982. Effect of cotton leaf curl crumple disease (CLC) on stab and planted cotton. Cotton. Coll. Agric. Rep. Ser., pp: 56. Cop. Ext. Ser. / Agric. Exp. Stn. Uni. Ariz./ Us. Dep. Agric., pp. 170.

Rahman, M., D, Hussain and Y. Zafar. 2002. Estimation of genetic divergence among elite cotton cultivars/genotypes by DNA fingerprinting technology. Crop Sci. 42, 2137-44.

Rahman M, D. Hussain, T. A. Malik and Y. Zafar. 2005. Genetics of resistance to cotton leaf curl disease in Gossypium hirsutum. Plant Pathol. 54:764-772.

Rashida, A. P., M. K, Sultan, Sultan, M. A, Khan and N. Sallam. 2005. Screening of cotton germplasm against cotton leaf curl begomovirus (CLCuV). J Agric Soc Sci. 1:235-238.

Rashid, M., A. A. Cheema and M. Ashraf. 2007. Clustering of basmati rice mutants by metroglyph analysis. Pak. J. Bot. 39:2043-2049.

Saeed, F., J. Farooq, A. Mahmood, M. Riaz, T. Hussain and A. Majeed. 2014. Assessment of genetic diversity for cotton leaf curl virus (CLCuD), fiber quality and some morphological traits using different statistical procedures in Gossypium hirsutum L. Australian J. Crop Sci. 8: 442-447.
Singh, D., J. S. Gill, R. K. Gumber, R. Singh and S. Singh. 2013. Yield and fibre quality associated with cotton leaf curl disease of Bt-cotton in Punjab. J Environ. Biol. 34:113-6.

Singh, P. and S. S. Narayanan. 1993. Biometrical techniques in plant breeding. Kalyani Pub.vNew Delhi, India.

Shakeel, A., F. M. Azhar and I. A. Khan. 2008. Variability in cotton ( $G$. hirsutum L.) genotypes for earliness. J. Agric. Res. 46:215-222.

Shakeel, A., J. Farooq, M. A. Ali, M. Riaz, A. Farooq, A. Saeed and M. F. Saleem. 2011. Inheritance pattern of earliness in cotton (Gossypium hirsutum L.). Aust. J. Crop. Sci. 5:1224-1231.

Steel, R. G. D., J. H. Torrie and D.A. Dickey. 1997. Principles and Procedures of Statistics. A biometrical Approach (3rd ed.). McGraw-Hill, New York.

Steel, R. G. D. and J. H. Torrie. 1997. Principles and Procedures of Statistics: A Biometrical.

Approach, 3rd edition. McGraw-Hill, New York.

Tyagi, P., M. A. Gore, D. T. Bowman, T. B. Campbell and J. A. Udall. 2014. Genetic diversity and population structure in the US Upland cotton (Gossypium hirsutum L.). Theor. Appli. 127:283-295. 